\title{
Between Fiction and Physiology: Brain Fever in The Brothers Karamazov and Its English Afterlife
}

\author{
JACOB EMERY AND ELIZABETH F. GEBALLE
}

JACOB EMERY, associate professor of Slavic and comparative literature at Indiana University, Bloomington, is the coeditor of the Svetlana Boym Reader (Bloomsbury Academic, 2018) and the author of Alternative Kinships: Economy and Family in Russian Modernism (Northern Illinois UP, 2017), as well as dozens of articles on topics ranging from medieval coins to aerial photography. $\mathrm{He}$ is working on two long-term projects: one on clone narratives (portions of which have been published in Science Fiction Studies) and the other on the artwork as it is framed by other kinds of work (portions of which have appeared in Comparative Literature and The New Left Review).

ELIZABETH F. GEBALLE, assistant professor in the Department of Slavic and East European Languages and Cultures at Indiana University, Bloomington, is the author of articles that track the translation and adaptation of nineteenth-century Russian literature, including "Literary Disorders and Translation Treatment: Curing Chekhov's 'The Black Monk,'” in Literature and Medicine, and "How Is the Fly Fallen, Fallen: The Sacrificed Insects of Anton Chekhov and Katherine Mansfield," in the Slavic and East European Journal. She is working on a book that explores the translation strategies of Leo Tolstoy and Fyodor Dostoevsky.
T HE NARRATOR OF WALKER PERCY'S 1966 NOVEL THE LAST GENtleman remarks that a character in a Russian novel "was sick with brain fever, whatever that is" and that he has "only come across brain fever in Russian novels" (250). In fact, characters are diagnosed with brain fever in English fiction by Emily Brontë, William Thackeray, and Charles Dickens, along with scores of other nineteenth-century authors. ${ }^{1}$ The disease's Latin equivalent, empresma cephalitis, appears in medical dictionaries alongside vernacular translations that are used more or less accurately by writers across the range of European languages; Gustave Flaubert, a scrupulous researcher who grew up in the hospital supervised by his father, has Emma Bovary diagnosed with fièvre cérébrale ("brain fever") by her husband, a medical professional (392). The Russian equivalents, nervnaia goriachka (нервная горячка) or nervnaia likhoradka (нервная лихорадка), do not even appear in the novel to which Percy's narrator refers, although brain fever appears three times in the English translation that Percy must have read (Goncharov, Precipice 66, 82, 83). The claim is, then, evidently mistaken: brain fever occurs in all kinds of literary traditions besides the Russian novel, and the instance Percy has in mind is an artifact of erroneous translation.

Yet The Last Gentleman is only one of many data points suggesting that brain fever has a special association, for English-language readers, with Russian literature and above all with the work of Fyodor Dostoevsky. Valerie Sayers's 1996 novel Brain Fever describes the disease not in medical terms but as a literary reference-a "Dostoevskian buzz" and "a longing for God" $(37,272)$. On the more comic end of the spectrum, the 1974 farce The Idiots Karamazov, in the original production of which Meryl Streep played the indefatigable translator Constance Garnett, introduces Ivan with the stage direction "Enter

(C) 2020 JACOB EMERY AND ELIZABETH F. GEBALLE

PMLA 135.5 (2020), published by the Modern Language Association of America

895 
Ivan, suffering from brain fever" (Durang and Innaurato 41). Critics who have no Russian have even written scholarly articles on brain fever in Dostoevsky. The association is due, no doubt, to the term's striking frequency in Garnett's translations of Dostoevsky. While brain fever appears twenty-five times in her translations of Dostoevsky (nine times in The Brothers Karamazov alone), it never appears in her translations of Leo Tolstoy, Ivan Turgenev, or any other Russian author. Only once, in Dostoevsky's The Eternal Husband, does brain fever translate the phrase nervnaia goriachka, which is its equivalent in Russian medical terminology (49; 9: 43); Garnett does sometimes render it using the medically acceptable synonym "nervous fever." ${ }^{2}$ Rather, brain fever stands in for phrases ranging from the simple goriachka (горячка; "fever") to vospalenie mozga (воспаление мозга; "inflammation of the brain") to belaia goriachka (белая горячка; “delirium tremens," or, colloquially, just “delirium”).

Brain fever thus appears in English to have been radically decoupled from its medical context, at least for the generation of readers who came of age with Garnett's translations, and the term's currency as a literary reference has outlasted its usage in medicine itself-a testament to the lasting influence of the pioneering translator of Russian literature into English. The anglophone world's "Dostoevsky cult" of the nineteen teens and twenties was, as Rachel May notes, "not just a cult of Dostoevsky, but a cult of Dostoevsky via Constance Garnett" (32). However, the muddled evolution of a medical into a literary term provides an opportunity to examine not just the role of medical terminology in Dostoevsky's fiction or its English translations but also the way literary discourse complicates the translation of medical terms, which might in a novel carry rhetorical functions or be implicated in thematic structures that are distinct from their nosological usages. Garnett's interpolation of brain fevers into Dostoevsky's fiction constitutes a case history of translation's providing concrete vocabulary for a set of issues that permeate the original-key Dostoevskian concerns of human suffering, responsibility for sin, and the tension between spiritual and materialist explanations of the world.

\section{Brain Fever between English and Russian}

Until germ theory became predominant in the early twentieth century, brain fever-empresma cephalitis, in Western medicine's universal language of reference - referred to brain inflammation brought on by emotional strain. Its ancient ancestor is Hippocrates's phrenitis, which Robert Burton defined in the early modern era as "a disease of the mind, with a continual madness or dotage, which hath an acute fever annexed" (1: 140). By the mid-1700s, medical science had come to consider fever as a pathologically rapid movement of blood that could have its seat in any organ but was most dangerous if it settled in the brain. The relevant complex of symptoms is amply described by medical reference books in every European language. The Russian Academy of Sciences in 1806 defines goriachka, fever, as "a disease consisting in the powerful movement of the blood" ("Goriachka"), and Vladimir Dal's 1863-66 dictionary describes nervicheskaia goriachka (нервическая горячка), brain fever, as a fever essentially "afflicting the brain and cortical veins" ("Nervicheskaia goriachka"). Thomas Mills's 1818 Morbid Anatomy of the Brain in Typhus or Brain-Fever describes thirty-seven case histories of "congestion and increased action of the vessels of the brain" and recommends as treatment "venesection, cathartics, and the application of leeches to the temples" (31). A 1907 dictionary of calques defines nervnaia goriachka as "nervous collapse accompanied by fever, an antiquated term for typhus" ("Nervnaia goriachka"). The reference to an antiquated term for typhus in both the Russian dictionary entry and in the title 
of Mills's book testifies to how closely Russian medical usage tracked that of the West. By the middle of the nineteenth century a water cure had replaced bleeding as the standard treatment, and by its end the discovery of microbes began to render the term anachronistic. The set of symptoms once associated with brain fever became reattributed to various pathogens causing meningitis or encephalitis.

Readers of Victorian literature, however, might think of brain fever less as a medical diagnosis and more as a shopworn cliché fixed by long usage in sentimental fiction. The critic Pamela Gilbert defines brain fever as "that most convenient of all Victorian afflictions" (120), which "attacks a character after a severe emotional shock of any kind" (54). Erin Blakemore quips that, "given the frequency with which brain fevers afflicted fictitious, Victorian-era characters, you may have suspected it was a kind of faux public health crisis invented by novelists in need of a handy plot device." The disease was attractive to Victorian novelists precisely because of its medical association with emotional strain. Alexander Tweedie identified the cause of brain fever in 1833 as "a severe shock to the nervous system" brought on by "fear, anxiety, disappointments, ... intense study, want of sleep, ... any undue mental fatigue. ... The violence of the disease falls upon the brain and nervous system, producing what is emphatically termed brain fever" (qtd. in Peterson 448). Brain fever assigns "emotional causes to a disease which then follows a prescribed physiological course," as Audrey Peterson writes. "[T]he combination of emotional cause and physical effect made brain fever attractive to the novelist" (464). A scientifically verifiable index of strong emotion, brain fever is exploited by storytellers in more or less conscious ways. A character in Arthur Conan Doyle's Round the Red Lamp marvels at "the mysterious malady called brain fever, which always attacks the heroine after a crisis, but which is unknown under that name to the text books" (215)—but Doyle himself, a medical doctor, uses the term in three of the Sherlock Holmes stories to depict "an acute reaction to severe stress, a brief reactive psychosis" (Tolins 105; see also Balcells). It appears in George Meredith, when Lucy Feverel is prevented from seeing her wounded husband (299); in Emily Brontë, when Catherine Linton is forced to choose between Heathcliff and Edgar (134); and in Gustave Flaubert, when Emma Bovary receives Rodolphe's letter (141). Perhaps the most telling evidence that brain fever is an index of emotional crisis is that Thackeray's Becky Sharpe, attempting to extract sympathy from her listener, calculatedly evokes the disease as proof of emotional trauma, claiming to have suffered a brain fever when separated from her child (628).

By 1912, when Garnett translated The Brothers Karamazov, brain fever had already become a medical anachronism, and her use of the term seems to have been influenced more by its associations in British fiction than by its medical definition. The twentyfive brain fevers in her translations of Dostoevsky all refer to situations in which the symptoms can be interpreted as the result of emotional turmoil-Rogozhin after the murder of Nastasia Filipovna (vospalenie mozga ["воспаление мозга"; "inflammation of the brain”]), Raskolnikov's mother after her son's trial (goriachka [“горячка"; "fever”]), Stavrogin after his arrest (belaia goriachka [“белая горячка"; “delirium”]), or Katerina Ivanovna after the confrontation with Grushenka ( $g o$ riachka), to pick a spread of examples from the four major novels. ${ }^{4}$ The condition of emotional trauma met, Garnett renders a straightforward sentence like "Noch'iu s neiu sdelalsia bred, a nautro goriachka" ("Ночью с нею сделался бред, а наутро горячка" [Polnoe sobranie sochinenii 24: 22]), which translates word for word as "At night delirium set in, and in the morning fever," as "At night she began to be delirious, and in the morning she had brain-fever" (Gentle Spirit 28). Inversely, 
cases of nervnaia goriachka that are not directly related to a shocking event might find more general English equivalents, so that brain fever in Garnett's translation is less a term for a medical condition than the diagnosis of a literary cliché.

The critic Bernard J. Paris, clearly working under Garnett's influence as recently as 2008 , assumes that brain fever in Dostoevsky's day was used "to designate psychosomatic symptoms brought on by moral and emotional crises" (180). Indeed, there is a clear relation between Dostoevskian diseases whose onset is precipitated by a mental shock, the diseases that Garnett chose to call brain fever, and the more general idea that the state of the body reflects the state of the soul. The identification of the body with moral qualities inevitably makes disease evaluative, a defender of moral boundaries that strikes the transgressing organ. In sentimental fiction especially brain fever carries this function. Kate, the heroine of Rhoda Broughton's Not Wisely but Too Well, exists in a constant state of fever identified with sexual passion: the "hot and cold fits that one is subject to in typhus fever and in love" (22); twice in the novel, each time following a sensual temptation, she falls ill with a brain fever that serves both as a metaphoric climax and as a corrective measure, after which she devotes herself to purity and religion. Not just an index of moral crisis, the fever is at once the substitute for consummation and the punishment that rectifies the passionate body.

With the development of germ theory later in the century, books themselves became implicated in this slippage between the physical and moral. Gilbert describes how circulating libraries began, in the 1880 s, to destroy books that had been lent to households where contagious disease appeared; in a radical confusion of the codex with the organic body, experiments were even conducted in "inoculating" books with germs (55). In this context, one of the imperatives of the translator was to sanitize the literature brought into the social body. To the great amusement of Vladimir Nabokov (316), the translator of the first American edition of Tolstoy's Anna Karenina (1886) refrained from using the scandalous word pregnant, instead leaving the Russian beremenna (беременна) in the middle of an otherwise English utterance (199). The dangers of literature imported from abroad, especially from suspect peripheral nations like Russia, appear in terms that mix emotional infection and moral contagion with medical exposure.

To the anglophone world, Dostoevsky epitomized the attraction and the threat of infectious literature. Robert Louis Stevenson called Crime and Punishment "the greatest book I have read in ten years. . . . It was like having an illness" (qtd. in May 28). In a similar account of the book's morbid fascination, Helen Muchnic concludes that to read it "was to make oneself voluntarily ill, of an illness from which one can never completely recover" (16). Garnett's publisher wrote to her about her translation of The Brothers Karamazov that he was "leaving it up to you to tone down such passages as might be thought offensive in this country" (qtd. in Garnett 260). A review of the book in The Times Literary Supplement makes the hygienic subtext explicit, stating that "we owe it mainly, indeed we owe it almost entirely, to [Garnett] that Russian novels may now be read in sound and native English" (qtd. in May 37). The translator is here the quarantine agent or, as May puts it, "the servant of the receiving culture, essentially a soldier called to heroic battle ... in the cause of transporting, or importing, another culture" (37). The translation-as-colonialism trope has here been medicalized: Garnett's translations, which participate in England's assimilation and essentialization of the texts of peripheral cultures, subdue but also pathologize morbid Russian texts (Bassnett).

Garnett's assimilation of the rich proliferation of mental disorders in Dostoevsky to a native English cliché can thus be contextu- 
alized within a perception of Russian fiction as emotionally overwhelming and morally unhygienic in its original state, rendered safe for English consumption only after the intervention of the translator. The canonical mediator of Russian literature for the Englishspeaking world, Garnett possessed the "gift," in May's words, "of convincing her readers that she 'must be right'; far from questioning her translations, they accepted her word as Turgenev, as Chekhov, as Russian prose" (143; see also Nikoliukin 154). Garnett's choice to foreground brain fever seems to have influenced later translators, perhaps because they were unsure how to navigate the vocabulary of nineteenth-century medicine and looked to her for guidance, or perhaps because brain fever had already become inextricably associated with Dostoevsky. In Crime and Punishment, David Magarshack, like Garnett, uses "brain fever" to describe the illness of Raskolnikov's mother (549), while the original reads simply "goriachka" (“горячка" [6: 415]). Henry and Olga Carlisle interpolate a brand new "brain fever" into The Idiot (41), where Garnett uses "delirium" to translate "goriachka" (37; 8: 35). The translation of The Brothers Karamazov that has entered into standard use in classrooms, prepared in 1990 by Richard Pevear and Larissa Volokhonsky, uses brain fever eight times, five following Garnett's lead and three where Garnett uses other terms, such as "fever" and "delirium." 5 Again, none of these correspond to the three instances in which the equivalent medical terms nervnaia goriachka (14: 464, 15: 38) and nervnaia likhoradka appear in the Russian text (15: 183). Indeed, the book to which Percy's character refers, in which goriachka, or simply "fever," is three times translated as "brain fever," is not by Dostoevsky and not translated by Garnett-it is Ivan Goncharov's The Precipice, translated by M. Bryant in 1915, three years after Garnett's prominent translation of The Brothers Karamazov. ${ }^{6}$ Already we are dealing not with an idiosyncratic translation choice by one individual but with a kind of filter through which anglophone readers, even translators and professional critics, are predisposed to perceive illness in Russian literature.

\section{Brain Fever between Medicine and Literature}

Admitting no liminal areas in its classifications and resorting to the sanctified language of Latin to prevent corruption of the term in living speech, the system of medical terminology-and by implication the system of scientific knowledge-aspires to an absolute semantic authority in which the body and its afflictions are rendered transparent, apprehensible, and eminently translatable. However, as Mikhail Bakhtin points out in an early essay, "secondary speech genres" such as novels "absorb and digest various primary (simple) genres that have taken form in unmediated speech communication," which then "enter into actual reality only via the novel as a whole, that is, as a literary-artistic event" ("Speech Genres" 62). As we have seen with the cliché of brain fever in Victorian sentimental fiction, even a rigidly categorized and conscientiously described medical term acquires, in literature, a symbolic value distinct from its medical use. As medical concepts like miasma, the humors, and brain fever lose their diagnostic value, secondary discourses might become the only active speech genres to lay claim to the associated terms, enmeshing them in a new context with a new function.

In this fashion, the astonishing concentration of brain fevers in the DostoevskyGarnett corpus has led to a general impression among anglophone readers unfamiliar with prebacterial nosology that something called "brain fever" is an exclusively Russian, exclusively literary symptom of spiritual flux. Naive critics have sometimes assumed that the term retains a consistent relation to medical discourse. Reed B. Merrill states in a 1976 article that "discussions of brain fever-or 
cerebral fever, or nervous fever, as it was also called-can be found in works of medical prognosis as early as the seventeenth century, but the most sophisticated fictional use of the term and its variants is in the novels of Fyodor Dostoevsky, where it is actually used as a narrative frame for Crime and Punishment and The Idiot" (29). What Merrill describes as a single "term" in fact corresponds to a wide range of idioms in the original Russian; if it has a fixed reference, it has to do with a literary cliché as emphasized in Garnett's translations rather than a medical condition. What is more, his claims that brain fever is a "narrative frame" for Crime and Punishment, that "Raskolnikov experiences a devastating attack of brain fever" (36), and that "his final attack of brain fever ... brings Raskolnikov into a state of salvation and resurrection" (38) are made in spite of the fact that Raskolnikov's illness is never referred to as nervnaia goriachka in Russian-or, indeed, as "brain fever" in any English translation. Nor would Raskolnikov's condition fit the cliché as Garnett understood it, since it precedes the traumatic event: Garnett uses brain fever in her translation of Crime and Punishment only once (to translate Dostoevsky's goriachka, used to describe the fatal illness Raskolnikov's mother suffers after her son's trial [474; 6: 415]). Merrill apparently applies the term to Raskolnikov by extension from other Dostoevsky books in Garnett's translation-suggesting a predisposition to see all manner of Dostoevskian illnesses, at least the philosophically fraught ones, as a literary device called brain fever.

To write, as Merrill does, that brain fever is a "term" that "concerns loss of ontological fixity resulting in alienation and often in mental derangement" and "receives its most comprehensive depiction in the works of Dostoevsky" (32) means that a distinctive literary phenomenon has become nameable or diagnosable in English as brain fever thanks to an artifact of idiosyncratic translation. Gary Saul Morson, a scholar of Russian literature who once quipped that "I have often thought that what I do for a living is teach the Collected Works of Constance Garnett" (qtd. in Malcolm), avers, in the course of a description of Dostoevsky's plotting devices, that "vortex time is almost always associated with mental disease or 'brain fever"' (Morson 167), a term whose Russian equivalent we have seen not to exist as such and which he leaves uncited. Rather, he shares Merrill's larger insight that Raskolnikov and other Dostoevsky characters are possessed of a common condition that is symptomatic of a lack of moral rootedness, an inability to distinguish between oneself and other people, and a zone of vertiginous narrative possibility-a state in which Raskolnikov remains until his symbolic Eastertime resurrection at the end of the novel. A literary symbol as well as a pathological state, brain fever now evokes Dostoevsky's standing preoccupation with the conflict between materialist and spiritual conceptions of human behavior: Did Raskolnikov commit murder because of his disturbed physical state, or was his physical agitation the result of his moral corrosion, his willingness to commit murder?

Dostoevsky's representation of morbid psychology may in this last sense originate in Carl Gustav Carus's 1846 treatise Psyche, sometimes considered a precursor to psychoanalysis. Joseph Frank surmises that Dostoevsky, who had contemplated undertaking a translation of the book into Russian, "would have eagerly seized on Carus' book as proof that one could be up-to-date and 'scientific,' without abandoning a belief in some sort of supernatural principle or in the precepts of Christian morality" (225). In 1955, the Cornell University professor George Gibian suggested that the condition Carus calls "diseased will," a disorder of the soul as a whole as opposed to organic and material symptoms localized in a part of the body, "is often called 'brain fever' (belaja gorjachka) in Dostoevsky" (377). Gibian cites a Russian medical term here, and one that Dostoevsky uses id- 
iosyncratically-but belaia goriachka correlates not with the English brain fever or the Latin empresma cephalitis but with delirium tremens. The hallucinatory symptoms associated with alcoholism might resemble those of Dostoevsky's characters-an encyclopedia from the 1890s describes them as "trembling, insomnia, and hallucinations. ... Psychical derangement is expressed so strongly that it is reminiscent of spiritual suffering" ("Belaia goriachka" [Entsiklopedicheskii slovar'])—but Dostoevsky typically uses the phrase in the more colloquial and now outdated sense of delirium in general.

This usage has become sufficiently disorienting to contemporary Russian readers that the culture and education Web site Arzamas, in an article entitled "Seven Secrets of Crime and Punishment," gloshes belaia goriachka as a condition characterized by "sudden and temporary mental disorders, not necessarily brought on by alcoholism" (Pershkina) and cites nineteenth-century critics who read the term in Dostoevsky in this sense ("O romane Prestuplenie i nakazanie"). Although we have found Russian medical sources to list only the alcohol-related meaning of belaia gori$a c h k a$, nineteenth-century general reference works like the 1895 dictionary of the Imperial Academy of Sciences include the sense "any sudden temporary insanity; delirium without fever" ("Belaia gorichka" [Slovar' russkago ia$z y k a]$ ). The major symptom of nervnaia goriachka, or brain fever, is, of course, fever. Thus, even if Dostoevsky's plan to translate Psyche never came to literal fruition, Gibian sees a terminology specific to Carus translated into a fictional discourse in Dostoevsky's novels, apparently based on an anachronistic English medical term in the translations of Constance Garnett, which he analogizes with a different medical term whose idiosyncratic colloquial usage is unusually frequent in Dostoevsky. Garnett does on six occasions translate belaia goriachka as "brain fever"-three times in The Possessed (42, 188, 322; 10: 43, 167, 276) and three in The Brothers Karamazov (685, 742, 770; 15: 70, 117, 142), but she by no means does so exclusively: in Crime and Punishment Raskolnikov is said three times to suffer from belaia goriachka (6: 89, 173, 173), which she translates in these instances as "raving" (105) and "high fever" $(205,205)$. Certainly belaia goriachka is not in a medical sense the same thing as brain fever or nervnaia goriachka; as a popular misappropriation of a medical term that departs from its terminological use, it might even be opposed to medical discourse.

What is astonishing in all this is not just how anglophone critics have tended to perceive a pathological state called brain fever across Dostoevsky's corpus but also the lengths to which they have gone to reassimilate this literary phenomenon to some established medical system-British nosology or German psychology-even as they attribute a Dostoevskian or an essentialized Russian quality to the disease. These translations between German, Russian, and English, and, perhaps most important, between scientific and fictional discourses, highlight a cluster of discursive factors deriving from the admixture of speech genres: Western European perception of its peripheral cultures, fiction as a vector of lexical evolution, the symbology of disease in both English and Russian texts, the authority of the translator, and especially the function of the term-the medically sanctioned word-as recontextualized in lay discourses. All these issues are closely interrelated: because of nineteenth-century medicine's theory that emotional strain caused brain fever, English novelists often used it as an indicator of emotional crisis; were it not for these associations with emotional collapse, Garnett would not have been so eager to project the disease onto Dostoevsky's melodramatic situations; and were it not for the assumed translatability of medical terminology, and for Garnett's status as the canonical ambassador of Russian fiction to the anglophone world, later English and American critics 
would not have been so ready to systematize Dostoevsky's literary constructions according to nineteenth-century nosological schemes.

\section{Brain Fever between Matter and Spirit}

Diagnostic confusion in Dostoevsky has long been used by literary critics and researchers in the medical humanities as a means of probing the depth and believability of his medical realism. For Joseph Collins in 1923, the fantastic mental processes of Dostoevsky's main characters are attempts to depict the soul's depth, and "the contents of the soul are most discernible in the mind that has some of its impenetralia removed by disease" (85). Yuri Zagvazdin, a scholar in the history of medicine, finds that Dostoevsky focuses on delirium and fever at the expense of "other specific signs of meningitis" (45), and Paris wonders whether it is even "appropriate" to treat Ivan's illness as part of a "mimetic depiction" (180). When readers and scholars aim at reintegrating the medical and literary discourses in the author's work, however, they are not wholly off the scent: Dostoevsky uses medical terms knowingly. Ivan Karamazov, diagnosed after his father's murder with nervnaia goriachka (15: 38), translated by Garnett as "nervous fever" (647), attempts to dispel his hallucinated devil by wrapping his head in wet cloth in order to reduce the temperature and blood pressure within the cerebral vessels. Dmitri too, "the day after his fate [is] determined," falls ill "with a nervous fever" (nervnaia likhoradka) and sits in the hospital "with a towel, soaked in vinegar and water, on his head" (822). In other words, Dostoevsky is careful to represent the disease he calls nervnaia goriachka not just as a spiritual crisis but also as a recognized pathology with a consistent etiology and symptoms, diagnosed by doctors and treated in accordance with medical norms.

Garnett muddies this point through her choice to translate various other terms in The Brothers Karamazov, like vospalenie v mozgu (14: 328) or belaia goriachka (15: 142), as "brain fever" $(388,685)$. This diagnostic flattening has the further effect of obscuring patterns of terminological confusion in the original text. Specified as nervnaia goriachka (15: 38) by a diegetic doctor character (and translated as "nervous fever" by Garnett [647]), Ivan's disease is subsequently called belaia goriachka (15: 117), translated as "brain fever" (742), by Alyosha during Ivan's testimony at Dmitri's trial. If Garnett's inconsistent usage assimilates the diagnosis of brain fever to literary clichés of emotional crisis and Edwardian assumptions about the commensurability between body and mind, we might with as much justice proceed in the other direction by examining Dostoevsky's own appropriation of medical discourse. In fact Garnett's decoupling of medical terminology and literary cliché, even if it comes about through lack of familiarity with Russian medical terms or with a desire to assimilate the excesses of Russian literature to Edwardian sensibilities, points to a tension between medical and lay discourses already operative in the original Russian-language text of The Brothers Karamazov.

"I have," Dostoevsky wrote in a letter to his editor (N. A. Liubimov) about his research into Ivan's hallucination,

for a long time consulted the opinion of doctors (and not only of one). They maintain that before a "cerebral fever" [belaia goriachka] not only are such nightmares possible, but also hallucinations. ... Here we find a physical (sick) trait when an individual at times begins to lose the distinction between the real and the illusory (which has happened to almost everybody at least once in his life), but also a moral trait which concurs with the hero's character: denying the reality of the illusion, when the illusion has disappeared, he stands up for its reality. (qtd. in Mochulsky, Dostoevsky 594) ${ }^{7}$

The letter makes clear Dostoevsky's efforts to be cognizant of medical norms, indeed to 
seek the approval of medical doctors for the consistency and plausibility of his representation of Ivan's disease. Yet it also marks the site of a terminological ambiguity. The condition Dostoevsky-like his character Alyoshacalls belaia goriachka, in quotation marks in a private letter, is diagnosed by a doctor in the novel as nervnaia goriachka, even though the terms are not synonymous and the first can even be read as marking the misappropriation of a medical term.

The terminological imprecision in this case appears to be not a symptom of Dostoevsky's troubled relationship with literary realism but an intentional undermining of medical discourse's specificity, comparable perhaps to the satirical use of foreign jargon in Tolstoy's scenes of medical diagnosis (in War and Peace, for instance, "the doctors ... spoke a great deal in French, Latin, and German" [655]). ${ }^{8}$ In Ivan's devil-haunted delirium Dostoevsky claims to approach the problem of distinguishing between the real and the unreal-which pertains as much to philosophy, theology, and fiction as to neurology-and to correlate it with the problem of distinguishing between the physical and the moral, that is, between the legible surface of the body's mental organs or nerves (nеrvy; “нервы”) and the obscure depth of the soul (dusha; "душа"). Describing Ivan's relation to his hallucination as a matter of "standing up" for an illusion and as a case history of the larger theological problem of belief in phenomena for which there is no material evidence, Dostoevsky points to the continuity between Ivan's illness and other major thematics of the novel: the problem of evidence, explored notably through Dmitri's trial, and the themes of faith healing and demonic apparitions that populate the parallel strands of the plot.

The book's narrator, who breaks in at critical junctures, stresses the contrast between medical and moral discourses at the onset of Ivan's hallucination, about which, as we know, Dostoevsky consulted multiple medical pro- fessionals. "I am not a doctor," the narrator announces in Garnett's translation, "but yet I feel that the moment has come when I must inevitably give the reader some account of the nature of Ivan's illness. Anticipating events I can say at least one thing: he was at that moment on the very eve of an attack of brain fever [belaia goriachka; белая горячка]" (685; 15: 70). Translated more literally, this passage reads, "And yet I feel that the moment has come when I absolutely must explain for the reader at least something about the character of Ivan Fedorovich's illness. To run ahead, I'll say just one thing: he was now, this night, exactly right on the eve of delirium."'

Our literal translation is awkward, but it highlights the narrator's self-effacing emphasis on his lack of medical qualifications, as well as the excessive abundance of specifiers that parody medical exactitude. $\mathrm{He}$ continues in the same vein, "Though I know nothing of medicine, I venture to hazard the suggestion that he really had perhaps, by a terrible effort of will, succeeded in delaying the attack for a time, hoping, of course, to check it completely" (685), ${ }^{10}$ and he further underscores his lay status by adding that Ivan has already consulted a specialist, who "after listening to and examining him" (“выслушав и осмотрев его") concluded that "he was actually suffering from some disorder of the brain" (“у него вроде даже как бы расстройства в мозгу” [686; 15: 70]). This comical paraphrase of a medical diagnosis is more comical yet in an alternative translation that accentuates the colloquial tone: "he even had something kind of, like, wrong with his brain." Echoing the real-life medical experts Dostoevsky consulted, the diegetic doctor proclaims that in Ivan's condition hallucinations are quite possible.

The terminological distinction between the colloquial belaia goriachka and the technical nervnaia goriachka becomes freighted here, since fifty pages earlier Katerina tells Alyosha that Ivan "has a fever, a nervous 
fever [nervnaia goriachka]! The doctor told me so" (647). ${ }^{11}$ The narrator's distracted paraphrase of nervnaia goriachka as "something kind of, like, wrong with his brain" is thus deliberately opposed to the accredited diagnosis confidently cited by Katerina. In fact the garbled parody resonates with Ivan's hallucinated devil, who complains that he suffers from a cold but has not sought medical treatment, since doctors "can diagnose beautifully, they have the whole of your disease at their finger-tips, but they've no idea how to cure you" (692). ${ }^{12}$ Because the major symptom of Ivan's disease is this demon, who debates theology with Ivan and actually describes himself in medical terms as a "homeopathic dose" ("gomeopaticheskie-to doli"; “гомеопатические-то доли”) of faith (697; 15: 79), it is clear that at the center of Ivan's condition is a tension between materialist and theological interpretations of the perceived world: is the devil a medical symptom or a visiting spirit? Yuri Lotman has cast this tension in semiotic terms as that prevailing in Dostoevsky between the denotational and symbolic poles, which are "constantly at odds with each other" and "make up the complex texture of his work": in his view Dostoevsky was, like a doctor or detective, a professed "decoder of symptoms" of social ills, even as his characters symbolize more obscure forces that are not transparent to reason (105).

We might understand the narrator's use of the colloquialism belaia goriachka as playing into the novel's running opposition between diagnostic and colloquial language, indeed as parodying medical discourse's claim to account for aberrant human behavior. The moral dimension of this claim, which would annul personal responsibility for criminal acts, is cultivated throughout the novel and comes to a head in the courtroom where Dmitri stands trial for the murder of his father. The visiting medical expert who diagnosed Ivan with nervnaia goriachka testifies to Dmitri's "condition of aberration [af- fekt; аффект] for several days before his arrest and, if a crime had been committed by him, it must, even if he were conscious of it, have been almost involuntary, as he had not the power to control the morbid impulse that possessed him" (727). Here, too, the narrator inserts his own claim to be a translator from one discourse to another: "It must be noted that I report this in my own words, the doctor made use of very learned and professional language" (727). ${ }^{13}$ Well in advance of Garnett's interventions, rewordings and their associated discursive shifts in the original text mediate between medicine and literature. Dostoevsky's destabilizing appropriation of materialist discourse makes his Russian narrator into a kind of translator, who by drawing medical diagnoses into the realm of the ambiguous and the ironic highlights Dostoevsky's performative digestion of a primary speech genre.

In the medical or materialist interpretation of the world, at least as paraphrased by the novel's characters, all phenomena are understood to affect one another according to laws of cause and effect on the granular level, so that people's actions are not their own responsibility but the consequence of more impersonal forces beyond their proper control. The widow Kokhlakova also produces a garbled paraphrase of the doctor's explanation: "A man may be sitting perfectly sane and suddenly have an aberration [affekt; аффект]. Не may be conscious and know what he is doing and yet be in a state of aberration. And there's no doubt that Dmitri Fyodorovich was suffering from aberration. They found out about aberration as soon as the law courts were reformed" (621-22). ${ }^{14}$ In the same way, Dmitri rehearses a mechanistic interpretation of consciousness in his paraphrase of the materialist Rakitin's explanation of axons and dendrites, which becomes in his retelling a confused mass of tails and devils:

Imagine: inside, in the nerves, in the headthat is, these nerves are there in the brain ... 
(devil take them) there are sort of little tails, the little tails of those nerves, and as soon as they begin quivering . . . that is, you see, I look at something with my eyes and then they begin quivering, those little tails ... and then something like a moment appears; that is, not a moment-devil take the moment!_but an image; that is, an object, or an action, devil take it! That's why I see and then think, because of those tails, not at all because I've got a soul, and that I am some sort of image and likeness. .. . It's magnificent, Alyosha, this science! . . . And yet I am sorry to lose God!

$(635 \text {; trans. modified })^{15}$

The garbling of medical discourse is a device the narrator shares with the characters and turns upon the question of whether phenomena of the imagination, like Ivan's devil or a nerve cell, have tails. Critics such as Michael Katz (71), Robert Belknap (75-76), Harriet Murav (145), and most recently Melissa Frazier (15) have noted that a reference to the French physiologist Claude Bernard, whose ideas were popularized in Russia by Ivan Sechenov, allows us to contextualize Dmitri's efforts to grapple with the neurological reduction of mental phenomena to material units within the larger history of Western neurology.

On a linguistic level, the competing pathological and spiritual interpretations of Ivan's hallucination evoke a contrast between two Russian idioms for a disordered consciousness. Is the world our brains represent to us a matter of excited nerves, whose disordered action remains the mechanical operation of a brain - that is, a nervous fever (nervnaia gorichaka, from nervy, nerves)-or are hallucinations the image and likeness of theological concepts, and mental illness hence a spiritual disease (dushevnaia bolezn', дшевная болезнь-another idiom meaning "psychological disorder," derived however not from physiology but from dusha, soul or spirit)? The systematic opposition of materialist and theological interpretations of the perceived world obliges the reader to choose between mutually exclusive diagnoses that stem from mutually exclusive discourses for mediating between the imagination and the empirical world: is the devil a medical symptom or a visiting spirit? If Dostoevsky promotes the literary functions of medical terminology in order to contest the hegemonic aspirations of Enlightenment rationality, so too does Garnett turn the antiquated medical term brain fever to a literary purpose in elevating it as a catchall diagnosis in her translations, in which the term's effect is to reduce the pathological threat of Dostoevsky's discourse in English. Although Garnett seems to internalize Dostoevsky's logic of appropriation of medical discourse through literal or figurative translation, she does so precisely by undermining the terminological precision whereby belaia goriachka and nervnaia goriachka are implicated in antithetical discourses and in mutually exclusive philosophical systems. In Garnett's translation, for instance, we do not see how the doctor's authoritative nervnaia goriachka becomes translated into its anti-Enlightenment version when Alyosha-the Karamazov family's spiritual bulwark and mouthpiece of faith-cries out in the courtroom during Ivan's testimony, "He is ill. Don't believe him: he has brain fever [v beloi goriachke]" (742), ${ }^{16}$ elevating personal faith above the empirical proofs elicited by secular institutions of judgment.

What does come through in Garnett's English versions is the Dostoevskian function of mental disorders in general: the complex we can, thanks to her, call brain fever, which involves loss of self, dissolution of plot time, and the transgression of moral boundaries, above all parricide. Sigmund Freud famously diagnoses Dostoevsky's own affliction-epilepsy, which he shares with the fictional Smerdiakov-as an expression of Oedipal guilt over his father's murder by his much-abused serfs (103); while Dmitri, Ivan, and Smerdiakov all become physically ill after performing actions that implicate them in the murder of their 
father, Alyosha chooses total subordination to a substitute father, the monastic elder Zosima, who can cure disease. Ivan makes explicit the identification of endemic disease with endemic guilt: "in every man ... a demon lies hidden - the demon of rage, the demon of lustful heat at the screams of a tortured victim, the demon of lawlessness let off the chain, the demon of diseases that follow on vice, gout, kidney disease, and so on" (254). ${ }^{17}$ Mere intent suffices to call down these diseases. A child, Iliusha, falls ill after feeding a dog a pin, and dies even though the dog does not: "It's because I killed Zhutchka, father, that I am ill now," Iliusha laments repeatedly on his deathbed (576). ${ }^{18}$ We have in Dostoevsky's fiction, writes Slobodanka Vladiv-Glover, "an oedipalized model of consciousness in which guilt and abjection are innate, leading to the re-absorption of the transgressor into the all-inclusive totality of the "Church'" (32). In this reading, the sin-and-redemption scheme of Christianity and the guilt-and-abjection scheme of psychoanalysis are mapped, in Dostoevsky, onto the affliction-and-cure model of disease. The disease is the physical manifestation of a character's guilt in rebellion against higher moral authority; it is also a necessary component of the sinner's progress toward subordination to that authority.

Dostoevsky's quarrel with medicine is that it places crime in a materialistic discourse in which sin can be interpreted as a symptom rather than a moral act. As Susan Sontag observes, "if criminal behavior can be considered an illness, then criminals are not to be condemned or punished but to be understood (as a doctor understands), treated, cured" (56). Medical science reiterates the heretical slogan of The Brothers Karamazov-if there is no God, then "everything would be lawful” ("vsyo budet pozvoleno"; “все будет позволено" [68; 14: 65])—not only through its grounding in atheistic rationalism but also through its claim that if all pathological behaviors are the consequence of impersonal material impulses, no one is responsible for those actions and no one is susceptible to punishment. The murderer-heroes of all Dostoevsky's late novels must therefore traverse the temptation to be absolved of their guilt by medical diagnosis. The jury at Raskolnikov's trial identifies his fever with the "fashionable theory of temporary insanity, so often applied in our days in criminal cases" $(480)^{19}$-but Raskolnikov only recounts the details of the murder and does not resort to this excuse. In The Idiot, Rogozhin's lawyers "proved ... that the crime committed was a consequence of the brain fever [vospalenie mozga; воспаление мозга] which had set in long before its perpetration" $(617)^{20}$-but Rogozhin too makes no attempt to adopt this defense. In The Possessed, Stavrogin's outrages are blamed on "brain fever" ("belaia goriachka"; “белая горячка" [42; 10: 43]); although he anticipates that no legal action will be taken because of the generally accredited notion of his derangement, Stavrogin states in his confession (suppressed from the initial Russian publication and therefore absent from Garnett's translation) that "I do not wish to refuse responsibility for my crimes on the grounds of either environment or disease" (our trans.). ${ }^{21}$ Indeed, the first philosophical conversation in The Brothers Karamazov-the discussion at Father Zosima's about whether Russia should be a Christian state governed by church law, or whether the church ought rather to absorb the state entirely-can be interpreted as framing this problem of secular justice grounded in material proofs versus religious morality grounded in individual abjection before judgment, since even an ecclesiastical court must exclude criminals from society on the basis of presented evidence, whereas in relation to the uncorrupted church all are guilty but no one is thereby excluded. Thanks to Garnett, brain fever has entered the anglophone consciousness with this meaning: the unmooring of the individual from a spiritual order defined by responsibility for others, and the materialist 
temptation of universal exculpation that must be consciously rejected in the name of a more mystical doctrine, a faith in universal mercy.

\section{Brain Fever between Fiction and Physiology}

Ivan's hallucination of the devil, which appears as a symptom of either a physiological or a spiritual ailment, is sourced from Dostoevsky's own hallucinations of the mid1840s - "an irritation of the entire nervous system," as Dostoevsky writes in a letter to his brother Mikhail on 26 April 1846, "barely contained by leeches and two blood-lettings," whose "treatment ... must be both physical and moral" (28). ${ }^{22}$ Dostoevsky's family physician reports that he would reassure the paranoid young author that his symptoms were the effects of a disordered nervous system: "the hallucinations come from the nerves" ("a galliutsinatsii-ot nervov"; “а галлюцинацииот нервов") and Dostoevsky would reply, "Of course, nerves" ("konechno, nervy"; “конечно, нервы” [Ianovskii 232]). Although critics are more commonly preoccupied with Dostoevsky's epilepsy, his earlier, hallucinatory illness is the likely ground for his insistent probing of the physiological roots of hallucinations, especially those marking religious crises. The tension inherent in Dostoevsky's own psychobiography-between mystic terror of a dark inhabiting force and the reassurance that it is "of course, nerves"gets played out time and again in The Brothers Karamazov. When the monk at the monastery sees evil spirits, should he engage in continual prayer or take "a special medicine" (“одного лекарства” [356; 14: 303])? When Lise confesses to Alyosha her dreams of devils, he ambiguously assures her that "it's a passing crisis; it's the result of your illness, perhaps" (627). ${ }^{23}$ Dostoevsky implies in each of these cases that hallucinations (and the crises of faith they marked) could perhaps be reduced to physiological origins, an attitude also reflected in his correspondence with men of medicine (Polnoe sobranie sochinenii 30.1: 236-37), who for their part are on record praising the plausibility of his medical representations (Rice 19). Even Dmitri's rant about nerves reflects a medical paradigm that reduces spiritual phenomena to local physiological pathologies, grounded in the research of Claude Bernard and perhaps influenced by Carus's account of how chronic fevers stimulate "the connectivity of the nerve fibers" (436; our trans.) and generate hallucinations including religious visions (440).

Yet Ivan's crucial conversation with his hallucinated devil seems to reflect another, more mystical claim from Carus that hallucinations are a "shadow on the conscious mind" (434) cast by some spiritual disturbance (Seelenkrankheit) of the unconscious that introduces into the essential unity of the soul the possibility of dialogue between its parts. This is the phenomenon Bakhtin foregrounds in his analysis of Ivan's hallucination as the fulfilment of the novel's tendency towards the polyphonic "coexistence and interaction" of multiple voices (Problems 30). In Bakhtin's poetic etiology of the hallucinated devil, Dostoevsky's "urge to see everything as coexisting, to perceive and show all things side by side and simultaneous," leads the author to dramatize "even internal contradictions and internal stages in the development of a single person-forcing a character to converse with his own double, with the devil, with his alter ego" (28). The medical anthropologist Byron Good has noted the usefulness of Bakhtinian approaches for thinking about illness more generally, since medical interpretations "always bear the history of the discourse that shapes its interpretation, and are always contested in settings of local power relations" (53). What we call a diagnosis, he argues, is manifested within a semantic network that is "culturally produced through struggle and perpetuated in a hegemonic form" (173), so that illness can most fruitfully be compared to aesthetic objects: the aesthetic text exceeds its 
medium, its words or its paint, just as the interpretation of an illness, which is synthesized into an objective narrative by coordinating a variety of discursive perspectives, exceeds the physiological experience of the symptoms.

Translation, of course, is also the cultural production of an acceptable text through a struggle with source material that inevitably exceeds its rendering into another tongue. According to Walter Benjamin, translation draws attention to the surplus of language that remains after utilitarian communication has been accomplished; medical discourse is a suggestive model for how translation and diagnosis operate as interrelated modes of taming that linguistic excess through a corresponding surplus of diagnosis that takes shape above and beyond the symptoms. The elements Good stresses as "history of discourse" and "power relations" are evident in Garnett's use of the antiquated term brain fever and in her effort to sanitize Russian literature for English consumption, as is the term's perpetuation in a "hegemonic form" in anglophone letters, even when its explicit function is to be explanatory or even curative. Lawrence Venuti coined the term domestication to describe translation strategies that reduce the information of the source text by conforming to the target text's culture, as when Garnett's adherence to the conventions of sentimental fiction erases Dostoevsky's systematic distinction between two languages describing mental disorders: specialized medical terminology and the anti-intellectual word of the bumbling layman (Venuti 19). Yet in the same stroke Garnett points to a profound connection between the medical humanities and translation studies, since brain fever becomes both a culturally specific diagnosis for mental disorders in Dostoevsky's fiction and a demonstration of how translation achieves linguistic and diagnostic mastery over the terminological excess of original texts. Such mastery operates not just on the level suggested by puns on a "body" of work or wordplay on the inoculatory intro- duction of foreign matter into a literary culture but also on the level of discourse itself.

The Brothers Karamazov provides an exceptional measure of medical distance traveled in translation because it is explicitly involved in the discursive struggle between medical science and mystical belief over pathological phenomena. Ivan and Alyosha, the intellectual and the saint, are children of a klikusha (“кликуша")-literally, a "shrieker," a term for women who make involuntary cries and are subject to fits or fainting-and Alyosha is said to resemble her in his hysterical symptoms (164). Klikushestvo can be interpreted as a culturally specific elaboration of the startle reflex and in this respect resembles perhaps the most widely studied culturebound syndrome, the Southeast Asian latah (Khristoforova 151). This condition especially affects lower-class widows and involves echopraxia, echolalia, and the production of cries and obscenities; the element of social struggle as manifested in bodily experience is evident in the transgressive speech of these marginalized women, as well as in their compulsion to obey commands and repeat words and gestures (Good 174-75). The narrator of The Brothers Karamazov suggests in the same vein that klikushestvo stems from the marginal social position of peasant women (Knapp 37).

Although folk belief dating back at least to the medieval period ascribed klikushestvo to demonic possession or ensorcellment, in the second half of the nineteenth century many accounts of the syndrome as a nervous pathology were published "in connection with the appearance and development in Russia and abroad of new conceptions of psychiatry" (Khristoforova 119). Susceptible to either a religious or a medical interpretation, klikushestvo in the late nineteenth century thus constituted, in Christine Worobec's words, "an arena within which two worldsone of popular Orthodoxy and the other of secular rationalism-collided and at times converged" (11). To be sure, Dostoevsky em- 
ploys klikushestvo as part of a constructed ideology of authentic Russianness, and Worobec describes in a brief reading how Alyosha's association with it encodes sympathies with peasant mysticism (136-40). However, introduced as it is early in The Brothers Karamazov, klikushestvo also acquires a privileged function to frame other illnesses, especially Ivan's and Dmitri's fevers and Smerdiakov's epilepsy-ailments whose objective reality is similarly in question and that serve the brothers as potential alibis in the case of their father's murder. Implicated in this fashion in questions of criminal responsibility, klikushestvo also frames the struggle between religious and secular law, since Father Zosima's activity as a faith healer, especially of kli$k u s h i$, prompts the important discussion that we mentioned above, about whether a Christian legal court is possible. Father Zosima's role as faith healer of a condition commonly believed to be demonic possession-a role in which we first encounter him-is reversed when he allows a monk who is tormented by hallucinated devils to take medicine to treat his nervous condition, for which he is lambasted by more rigidly dogmatic monks. As we have seen, Dostoevsky extends this struggle between secular and mystical interpretations of nervous symptoms into the novel's many subplots, medicalizing moral dilemmas and spiritualizing physical disabilities.

In Garnett's translation, as in Russian folk belief, klikushi are "possessed by devils" (11) - a word choice determined, like "brain fever," by its culturally specific literary associations. Resolving the condition's ambiguous susceptibility to medical and religious interpretations in favor of the latter, "possessed by devils" takes on an exoticizing function in fixing the phenomenon as a supernatural one, an element of Russian culture opposed to the universality of physiological and psychological norms assumed by Western medicine and Enlightenment rationality (see Knapp). A literal but foreignizing translation like "shriek- ing" forecloses this interpretation by referring to a symptom that is perfectly specific but at the same time lacks meaning in the medical horizon of anglophone reference. If literature, as Good suggests, is paradigmatic of the cultural, discursive, and ideological pressures that attend acts of diagnosis, then translation exaggerates and deepens the space between symptomology and terminology, which perpetually shifts to account for the disorders of the original text in a culturally sound hostlanguage narrative. In The Translator in the Text, May suggestively aligns translation and psychoanalysis, quoting Peter Brooks to observe that translators, like analysts, "help ... construct a more coherent, connected, and forceful narrative discourse, one whose syntax and rhetoric are more convincing, more adequate, to give an interpretive account of the story of the past than those that are originally presented, in symptomatic form, by the analysand" (85). Triangulating mental health, fiction, and translation, May's model positions translation as a cure to the original text, suggesting that every translation can be thought of as a parallel narrative that claims to diagnose, etiologize, and ultimately to resolve the erratic disorders and discursive conflicts that play out on the lexical-that is, the terminological-level of the original text. On the one hand, texts are constituted by the tensions that translation, in its hypostasis as an Enlightenment effort to normalize and make transparent the obscurity of alien phenomena, seeks to classify and dispel; on the other, every translation is an interpretive account of a mass of words that acquire cultural meaning, including that of struggle or of the transcendental, only through their more-or-less conflicted transposition into the structures of discourse.

In Dostoevsky's world, any process that reduces guilt, spiritual crisis, and moral infection to medical disorders is, in the final analysis, a devilish activity. The devil himself-who is perhaps a product of the imagination of Ivan, the preeminent authorial 
figure of The Brothers Karamazov-suggests that "artistic visions" ("khudozhestvenniye sny"; "художественные сны”) and "plot" (“intriga”; “интрига") are only dreams born of "indigestion" ("ot rasstroistva zheludka"; “от расстройства желудка" [691; 15: 74]). We see in Dostoevsky's research his efforts to conform to both medical norms and literary exigencies, if only to play the two discourses off against each other. Although Garnett's translations might aspire to resolve the conflict by using a literary commonplace that implies the universality of medical or narrative norms across cultures and languages, in the end "brain fever" might not so much obscure as provide a name for Dostoevsky's preoccupation with the problem of medical diagnosis in relation to spiritual life, and hence with the tension between the universalistic claims of Enlightenment materialism and the equally universalistic claims of Christian mysticism. Benjamin typifies translation as a kind of "afterlife" in which "even words with fixed meanings can undergo a maturing process" (73). Far from an antiquated disease or a cliché of sentimental literature, or even a simple mistranslation, brain fever can now be read as English shorthand for the spiritual crises that structure the development of Dostoevsky's novels, for the problem of guilt as contested by secular and religious institutions, and as a suggestive bridge between the discourses of fiction and physiology.

\section{NOTES}

The authors would like to thank Marc Shell and William Mills Todd III, in whose graduate seminars early tributaries of this essay took shape; Harvard's Davis Center for Russian and Eastern European Studies, which provided funding for research in medical libraries in Russia; and Alex Spektor and Russell Valentino, who commented on early drafts of this essay.

1. See, e.g., Brontë 118; Thackeray 628; Dickens 204.

2. Our quotations from Dostoevsky's work are taken from Constance Garnett's translations unless otherwise specified. Page-number citations of Garnett's translations are followed by citations of volume and page numbers of the corresponding passages in the Russian original as they appear in the standard edition of Dostoevsky's collected works (Полное собрание сочинений в 30 томах) [Polnoe sobranie sochinenii v 30-i tomakh]. All other translations are ours unless otherwise noted.

3. Nervicheskaia is an antiquated variant of nervnaia; hence, nervicheskaia goriachka and nervnaia goriachka are equivalent.

4. The Idiot 617 (8: 507); Crime and Punishment 484 (6: 415); The Possessed 42 (10: 43); The Brothers Karamazov 223 (14: 194).

5. In Pevear and Volokhonsky's translation, brain fever appears on pages $213,364,367,634,691,692,760$, and 761. Garnett's translation is the source of the term five times $(223,388,685,747$, and 749$)$ but does not use brain fever on pages 391,820 , and 821 .

6. The instances of goriachka that Bryant translates as brain fever can be found in volume 7 of the Russian edition on pages 463,558 , and 561 .

7. “Я давно уже справлялся с мнением докторов (и не одного). Они утверждают, что не только подобные кошмары, но и галлюцинации перед 'белой горячкой’ возможны. Мой герой, конечно, видит и галлюцинации, но смешивает их и со своими кошмарами. Тут не только физическая (болезненная) черта, когда человек начинает временами терять различие между реальным и призрачным (что почти с каждым человеком хоть раз в жизни случалось), но и душевная, совпадающая с характером героя: отрицая реальность призрака, он, когда исчез призрак, стоит за его реальность" (Mochulsky, Dostevskii 488).

8. “Доктора . . . говорили много по-французски, и по-немецки, и по-латыни” (Tolstoy, Polnoe sobranie sochinenii 11: 65 ).

9. The original reads, “а между тем чувствую, что пришла минута, когда мне решительно необходимо объяснить хоть что-нибудь в свойстве болезни Ивана Федоровича читателю. Забегая вперед, скажу лишь одно: он был теперь, в этот вечер, именно как раз накануне белой горячки.”

10. “Не зная ничего в медицине, рискну высказать предположение, что действительно, может быть, ужасным напряжением воли своей он успел на время отдалить болезнь, мечтая, разумеется, совсем преодолеть ее” (15: 70).

11. “. . . у него горячка, нервная горячка! Мне доктор говорил” (15: 38).

12. “. . . распознать умеют отлично, всю болезнь расскажут тебе как по пальцам, ну а вылечить не умеют" (15: 76).

13. “Я передаю своими словами, доктор же изъяснялся очень ученым и специальным языком” (15: 104)

14. “Сидит человек совсем не сумасшедший, только вдруг у него аффект. Он и помнит себя и 
знает, что делает, а между тем он в аффекте. Ну так вот и с Дмитрием Федоровичем, наверно, был аффект. Это как новые суды открыли, так сейчас и узнали про аффект" (15: 18).

15. “Вообрази себе: это там в нервах, в голове, то есть там в мозгу эти нервы (ну черт их возьми!) . . . есть такие этакие хвостики, у нервов этих хвостики, ну, и как только они там задрожат ... то есть видишь, я посмотрю на что-нибудь глазами, вот так, и они задрожат, хвостики-то . . . а как задрожат, то и является образ, и не сейчас является, а там какое-то мгновение, секунда такая пройдет, и является такой будто бы момент, то есть не момент,- черт его дери момент,- a образ, то есть предмет али происшествие, ну там черт дери - вот почему я и созерцаю, а потом мыслю... потому что хвостики, а вовсе не потому, что у меня душа и что я там какой-то образ и подобие. . . . Великолепна, Алеша, эта наука! Новый человек пойдет, это-то я понимаю. . . . А все-таки бога жалко!” (15: 28).

16. “Он болен, не верьте ему, он в белой горячке!” (15: 117).

17. “Во всяком человеке . . . таится зверь, зверь гневливости, зверь сладострастной распаляемости от криков истязуемой жертвы, зверь без удержу, спущенного с цепи, зверь нажитых в разврате болезней, подагр, больных печенок и проч” (14: 220).

18. “Это я за то болен, что я собаке Жучке” (15: 312).

19. “. . . новейшая модная теория временного умопомешательства, которую так часто ста-раются применять в наше время к иным преступникам" (6: 411).

20. “. . . что совершившееся преступление было следствием воспаления мозга, начавшегося еще задолго до преступления вследствие огорчений подсудимого” (8: 507).

21. “. . . я ни средой, ни болезнями безответственности в преступлениях моих искать не хочу” (11: 14).

22. “Болен я был . . . раздражением всей нервной системы ... . едва удержано было пьявками и двумя кровопусканиями. . . . Лечение же мое должно быть и физическое и нравственное" (1: 121).

23. “. . . минутный кризис, в этом ваша прежняя болезнь, может быть, виновата” (15: 22).

\section{Works Cited}

Bakhtin, Mikhail. Problems of Dostoevsky's Poetics. U of Minnesota P, 1984.

_. "Speech Genres" and Other Late Essays. U of Texas P, 1986.

Balcells, M. "Medical and Neurological References in the Sherlock Holmes Stories." Neurosciences and History, vol. 1, no. 3, 2013, pp. 137-43.

Bassnett, Susan. Post-colonial Translation: Theory and Practice. Routledge, 1999.
“Белая горячка" [“Belaia goriachka”; "Delirium tremens”] Знциклопедичский словарь [Entsiklopedicheskii slovar': Encyclopedic Dictionary]. Efron, 1890-1904.

“Белая горячка" ["Belaia goriachka”; "Delirium tremens”]. Словарь русского языка [Slovar' russkago iazyka; Russian Language Dictionary], Tipografiia Imperaterskoi Akademii Nauk, 1895.

Belknap, Robert. The Genesis of The Brothers Karamazov. Northwestern UP, 1990.

Benjamin, Walter. Illuminations. Translated by Harry Zohn, Schooken Books, 1968.

Blakemore, Erin. "Did the Victorians Really Get Brain Fever?" JSTOR Daily, 30 Mar. 2017, daily.jstor.org/did -victorians-really-get-brain-fever/.

Brontë, Emily. Wuthering Heights. Oxford UP, 1976.

Broughton, Rhoda. Not Wisely but Too Well. Tauchnitz, 1867.

Burton, Robert. The Anatomy of Melancholy. J. M. Dent, 1932. 3 vols.

Carus, Carl Gustav. Psyche: Zur Entwicklungsgeschichte der Seele. Pforzheim, Flammer und Hoffmann, 1846.

Collins, Joseph. The Doctor Looks at Literature. George H. Doran, 1923.

Dickens, Charles. A Tale of Two Cities. Houghton, Osgood, 1873.

Dostoevsky, Fyodor. The Brothers Karamazov. Translated by Constance Garnett, Heinemann, 1912.

- The Brothers Karamazov. Translated by Richard Pevear and Larissa Volokhonsky, Farrar, Straus and Giroux, 2002.

. Crime and Punishment. Translated by Constance Garnett, Macmillan, 1914.

—. Crime and Punishment. Translated by David Magarshack, Penguin, 1961.

. "The Eternal Husband" and Other Stories. Trans-

lated by Constance Garnett, Heinemann, 1917.

- A Gentle Spirit. Translated by Constance Garnett, Kyros Press, 2016.

—. The Idiot. Translated by Constance Garnett, Heinemann, 1913.

- The Idiot. Translated by Henry Carlisle and Olga Carlisle, Signet Classics, 2010.

- Полное собрание сочинений в 30 томах [Polnoe sobranie sochinenii $v$ 30-i tomakh; The Complete Collected Works of Dostoevsky in 30 Volumes]. Nauka, 1972-90.

- The Possessed. Translated by Constance Garnett, Heinemann, 1914.

Doyle, Arthur Conan. Round the Red Lamp. Methuen, 1894.

Durang, Christopher, and Albert Innaurato. The Idiots Karamazov. Performance by Meryl Streep, Dramatists Play Service, 1981.

Flaubert, Gustave. Madame Bovary. Bibliothèque Charpentier, 1979. 
Frank, Joseph. A Writer in His Time. Princeton UP, 2009.

Frazier, Melissa. "The Science of Sensation: Dostoevsky, Wilkie Collins and the Detective Novel." Dostoevsky Studies, vol. 19, 2015, pp. 7-28.

Freud, Sigmund. "Dostoevsky and Parricide." Dostoevsky: A Collection of Critical Essays, edited by René Wellek, Prentice-Hall, 1962, pp. 98-111.

Garnett, Richard. Constance Garnett: A Heroic Life. Faber and Faber, 2009.

Gibian, George. "C. G. Carus' Psyche and Dostoevsky." The American Slavic and East European Review, vol. 14 , no. 3, 1955, pp. 371-82.

Gilbert, Pamela K. Disease, Desire, and the Body in Victorian Women's Popular Novels. Cambridge UP, 1997.

Goncharov, Ivan. Полное собрание и сочинений и писем в 20 томах [Polnoe sobranie sochinenii i pisem $v$ 20-i tomakh; The Complete Collected Works and Letters in 20 Volumes]. Nauka, 1997-.

—. The Precipice. Translated by M. Bryant, Forgotten Books, 2012.

Good, Byron J. Medicine, Rationality, and Experience: An Anthropological Perspective. Cambridge UP, 1994.

"Горячка" [“Goriachka”; "Fever”]. Словарь Академии Российской [Slovar' Akademii Rossiskoi; Dictionary of the Russian Academy]. Imperatorskaia Akademiia Nauk, 1806-22.

Ianovskii, S. D. "Воспоминания о Достоевском" ["Vospominaniia o Dostoevskom"; "Memories of Dostoevsky"]. Ф. М. Достоевский в воспоминаниях современников [F. M. Dostoevskii v vospominaniiakh sovremennikov; F. M Dostoevsky in the Memoirs of His Contemporaries], edited by K. Tiun'kin and M. Tiun'kina, Khudozhenstvennaia literatura, 1990, pp. 230-51.

Katz, Michael. "Dostoevsky and Natural Science." Dostoevsky Studies, vol. 9, 1988, pp. 63-76.

Khristoforova, О. В. Одержимость в русской деревне [Oderzhimost' $v$ russkoi derevne; Spirit Possession in a Present-Day Russian Village]. Neolit, 2016.

Knapp, Liza. "Mothers and Sons in The Brothers Karamazov: Our Ladies of Skotoprigonevsk." A New Word on The Brothers Karamazov, edited by Robert Louis Jackson, Northwestern UP, 2004, pp. 31-52.

Lotman, Yuri. Universe of the Mind: A Semiotic Theory of Culture. Translated by Anne Shukman, U of Michigan P, 2000.

Malcolm, Janet. “Socks." The New York Review of Books, 23 July 2006, www.nybooks.com/articles/2016/06/23/ socks-translating-anna-karenina/.

May, Rachel. The Translator in the Text: On Reading Russian Literature in English. Northwestern UP, 1994.

Meredith, George. The Ordeal of Richard Feverel. Archibald Constable, 1896. Vol. 2 of The Works of George Meredith.

Merrill, Reed B. "Brain Fever in the Novels of Dostoevsky." The Texas Triquarterly, vol. 19, no. 3, 1976, pp. 29-50.
Mills, Thomas. Morbid Anatomy of the Brain in Typhus or Brain-Fever. 2nd edition, Hodges and McArthur, 1818.

Mochulsky, Konstantin. Достоевский: жизнь и творчество [Dostoevskii: zhizn' i tvorchestvo; Dostoevsky: His Life and Work]. YMCA Press, 1980.

- Dostoevsky: His Life and Work. Translated by Michael A. Minihan, Princeton UP, 1967.

Morson, Gary Saul. Narrative and Freedom. Yale UP, 1994.

Muchnic, Helen. Dostoevsky's English Reputation, 18811936. Octagon Books, 1969.

Murav, Harriet. Holy Foolishness: Dostoevsky's Novels and the Poetics of Cultural Critique. Stanford UP, 1993.

Nabakov, Vladimir. Lectures on Russian Literature. Harcourt, 1981.

“Нервическая горячка” [“Nervicheskaia goriachka”; "Brain fever"]. Толковый словарь живого великорусского языка [Tolkovyi slovar' zhivogo velikorusskago iazyka; Explanatory Dictionary of the Living Great Russian Language], by Vladimir Dal', M. O. Vol'v, 1905.

“Нервная горячка" ["Nervnaia goriachka”; "Brain fever"]. Словарь иностранных слов, вошедших в состав русского языка [Slovar' inostrannykh slov, voshedshikh $v$ sostav russkago iazyka; Dictionary of Foreign Words in the Russian Language], Izdatel'stvo F. Pavlenkova, 1907.

Nikoliukin, A. N. “Достоевский в переводе Констанс Гарнет” ["Dostoevskii v perevode Konstans Garnet"; "Dostoevsky in the Translations of Constance Garnett”]. Русская литература [Russkaia literatura; Russian Literature], vol. 2, 1885, pp. 154-62.

Paris, Bernard J. Dostoevsky's Greatest Characters. Palgrave Macmillan, 2008.

Percy, Walker. The Last Gentleman. Picador USA, 1999.

Pershkina, Anastasia. "7 секретов Преступления и наказания” [“7 sekretov Prestuplenia i nakazania”; "Seven Secrets of Crime and Punishment"]. Arzamas, 23 Mar. 2017, arzamas.academy/mag/419-dost.

Peterson, Audrey C. "Brain Fever in Nineteenth-Century Literature: Fact and Fiction." Victorian Studies, no. 19, 1976, pp. 445-64.

Rice, James L. Dostoevsky and the Healing Art. Ardis, 1985. Sayers, Valerie. Brain Fever. Doubleday, 1996.

Sontag, Susan. Illness as Metaphor. Illness as Metaphor and AIDS and Its Metaphors. Doubleday, 1990, pp. 2-88.

Thackeray, William Makepeace. Vanity Fair. Wordsworth Editions, 1998.

Tolins, Stephen H. "Brain Fever." The Baker Street Journal, vol. 41, no. 2, 1991, pp. 104-09.

Tolstoy, Leo. Anna Karenina. Translated by Nathan Haskell Dole, Thomas Y. Crowell, 1886.

-. Полное собрание сочинений в 90 томах [Polnoe sobranie sochinenii $v 90$ tomakh; The Complete Collected Works of Tolstoy in 90 Volumes]. Khudozhestvennaia literature, 1928-1964. 
War and Peace. Translated by Richard Pevear and Larissa Volokhonsky, Vintage Classics, 2008.

Venuti, Lawrence. The Translator's Invisibility: A History of Translation. Routledge, 2008.

Vladiv-Glover, Slobodanka. "What Does Ivan Karamazov 'Know'? A Reading through Foucault's Analytic of the 'Clinical' Gaze." New Zealand Slavonic Journal, 1995, pp. 23-44.
Worobec, Christine D. Possessed: Women, Witches, and Demons in Imperial Russia. Northern Illinois UP, 2001.

Zagvazdin, Yuri. "Meningitis, a Whirlpool of Death: Literary Reflections and Russian Cultural Beliefs." Literature, Neurology, and Neuroscience: Neurological and Psychiatric Disorders, vol. 206, edited by Stanley Finger et al., 2013, pp. 35-58. 